\title{
"Festo" manifesto heard before US Supreme Court
}

$V^{2}$ aluable biotechnology intellectual property rights are very much up for grabs because of a patent dispute involving not genetic engineering, but arcane matters of mechanical engineering. During a heated debate in early January, the US Supreme Court heard oral arguments in the "Festo" case (Festo Corporation v. Shoketsu Kinzoku Kogyo Kabushiki Co. et al., Case No. 00-1543).

A ruling is expected no later than June from the nine members of the Supreme Court, who appear to take their review of Festo seriously and to understand its impact on inventors, industry, and the public, according to patent attorneys who are following the case. "The Supreme Court Justices are unlikely to rubber-stamp the lower court's decision," says patent attorney John Paul of Finnegan, Henderson, Farabow, Garrett \& Dunner, LLP (Finnegan; Washington, DC), referring to the justices.

The numbers and wording of several amicus briefs submitted to the Supreme Court vouch for how much is riding on this case. Already, the lower Federal Circuit court decision from November 2000 in "Festo" (Nat. Biotechnol. 19, 391, 394, 777, 2001) is changing patenting strategies and has affected a sizable number of lawsuits over patented technologies and the value of a large number of patents, according to patent attorney David Forman, also of Finnegan.

The circuit court ruling narrows the longstanding "doctrine of equivalents" in patent law, whereby a company with a particular product can keep others from introducing minor changes into that product while calling it different, even if essentially copying the invention. However, that ruling specifically addresses changes that inventors inevitably make in patent applications during negotiations with examiners in the US Patent and Trademark Office (PTO; Arlington, VA). According to the 2000 ruling, virtually any changes made to the claims that describe particular inventions effectively will narrow their scope and will reduce and could eliminate an inventor's right to recapture minor variations of a product (or process for making it) introduced by others who closely copy the invention and then infringe on its commercial use.

Because of the peculiar nuances embodied in many biotech products and in the patents that are intended to protect them, the stakes in this Festo review are particularly high for biotechnology companies. The circuit court ruling "radically undermines the patent system" and risks rendering some

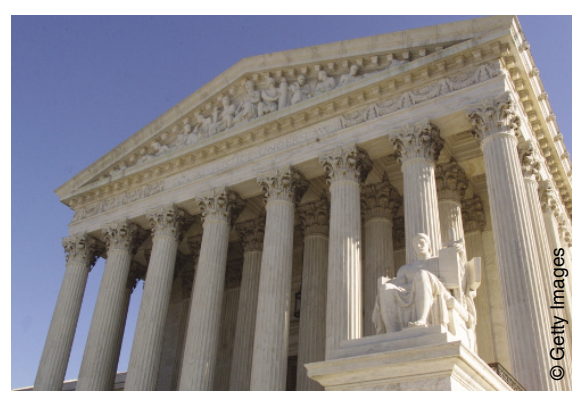

Some companies say the current Festo rulingbeing considered in the Supreme Court (above)-provides copyists with a fail-safe method to avoid liability for infringement.

1.2 million recently issued patents "virtually worthless," argue Festo attorney Robert Bork and his colleagues.

"The [circuit] court's decision has been in effect for 13 months, [and] it's really worked just fine," counters Attorney Arthur Neustadt of Oblon, Spivak, McClelland, Maier \& Neustadt PC (Arlington, VA), who urged the justices to leave the circuit court ruling on Festo intact. "Patent prosecution hasn't changed at all....It's simplified a lot of the decisions." In his written submission to the Court, Neustadt further argues that the ruling of the circuit court reflects its "unique expertise," and that it properly corrected a former practice that introduced "ineradicable uncertainty" into patenting and led to "costly and investment-deterring litigation."

Some biotechnology companies have lined up in support of Neustadt's arguments, whereas others vehemently disagree. Applera (Norwalk, CT), for example, urges the Supreme Court not to "re-evaluate the considered judgment of the Federal Circuit in its area of special expertise," discounting warnings of "doom and parades of horribles" if the ruling is left intact.

Many other biotechnology companies take the opposite side, however. For instance, attorneys representing Celltech (Slough, UK) say that the current ruling "provides copyists with a fail-safe method to avoid liability for infringement"-one that is especially suitable to biotechnology inventions, which have "special features." They point out that "slight modifications to biotechnology inventions, such as a change of one amino acid or nucleotide, are routine and often have no substantive impact on the molecule, but can defeat literal infringement." Adding a particularized dimension to the importance of this case, Celltech attorneys note that a UK Patents Court Judge has postponed deciding an infringement lawsuit brought by Celltech against MedImmune (Gaithersburg, MD) over "humanized" antibodies until the Supreme Court issues its ruling on Festo.

Agreeing with Celltech's position, and with similar vehemence, attorneys representing Chiron (Emeryville, CA) say that "the doctrine of equivalents is essential for biotechnology patents" and that, without that doctrine, "a gene patent would be valueless unless it claimed every equivalent sequence of nucleotides." Its attorneys also assert that the retroactive ruling of the circuit court "may be one of the most significant takings of existing property rights."

Criticism from the academic community whose faculty members collaborate with the industry is no milder. "In making this ruling, the Federal Circuit has placed in jeopardy 1.2 million existing patents," according to the brief submitted on behalf of a coalition of several research universities and institutions, including the Massachusetts Institute of Technology (Cambridge, MA). "At risk is the untold value of all existing US patents." Moreover, the ruling will "greatly increase" the costs of "acquiring, maintaining, and defending a patent portfolio."

Jeffrey L. Fox, Washington, DC

\section{CGIAR under pressure to support seed treaty}

A fter seven years of negotiation, an International Treaty on Plant Genetic Resources for Food and Agriculture was adopted by the Food and Agricultural Organization (FAO) of the United Nations in November 2001. Despite nominal support, the Consultative Group on International Agriculture Research (CGIAR; Washington, DC), which maintains up to $50 \%$ of the world's unduplicated seed samples, is facing political pressure to participate actively in the treaty and is set to discuss the implications at a high-level meeting on 18-20 February. The aim of the treaty is to provide effective legal rules to free up the exchange of seeds between countries for breeding and GM crop development, but the issue of plant genetic resources has been heavily influenced by the nongovernmental organization (NGO) 